\title{
Pelayanan Jamu Pada Ny.S dengan Peningkatan Kadar Asam Urat dalam Darah Tinggi di Penyehat Tradisional (HATRA) R. Klaten
}

\author{
Ari Wulandari ${ }^{1}$, Susilo Yulianto ${ }^{2 *}$ \\ ${ }^{1,2}$ Politeknik Kesehatan Surakarta, Jurusan Jamu \\ *Email : susilo_yulianto14@yahoo.co.id
}

\begin{abstract}
Background: Uric acid is a problem in the elderly, with symptoms of joint and heel pain every time you wake up in the morning, stiff on the fingers and toes and swelling and redness. The incidence of gout in the elderly accounted for 47 cases in Hatra R. One of the actions that can reduce uric acid levels is herbal medicine. Sidaguri types of herbs, kepel and bay leaves containing flavonoids, ethanol and hexane can inhibit the activity of xanthine oxidase enzymes that have the potential to reduce uric acid levels in the blood. The purpose of this study was to determine the service of herbal medicine in Mrs. S with high blood uric acid levels. Methods: This research is a descriptive type with a case study approach to 1 client with characteristics of pain in the right waist to the knee. Data collection techniques using the assessment of herbal services. Data validity test is done by triangulation technique based on source triangulation, namely getting information from the client, family, supporting examinations brought by the client, then technique trangulation is by interview and observation and time triangulation namely by checking the data carried out in an iterative time to get the results of the decline uric acid levels in the blood. Results: The results showed that the client's condition is the level of uric acid in the blood to be normal and the pain in the right knee to heal and be able to walk normally so the problem is resolved. Interventions conducted on the client are assessment, determining the problem with the client, determining planning, providing herbal medicine and evaluating services. The results of the evaluation of the action showed that the problem was resolved by decreasing the level of uric acid in the blood. Conclusion: The service of herbal medicine in Ny.S with increased levels of uric acid in the blood can reduce uric acid levels in the blood.
\end{abstract}

Keywords: case reports, herbal medicine services, high uric acid levels

\section{PENDAHULUAN}

Kadar asam urat dalam darah tinggi didefinisikan sebagai peningkatan kadar asam urat diatas normal (laki-laki > 7,0 $\mathrm{ml} / \mathrm{dl}$ dan wanita $>6,0 \mathrm{ml} / \mathrm{dl}$.). kadar asam urat dalam darah ditentukan oleh keseimbangan antara produksi $(10 \%$ klien) dan ekskresi (90\% klien). (Sholihah, 2014). Masalah asam urat yang terjadi di masyarakat begitu tinggi yaitu banyak yang mengalami keluhan seperti nyeri pada sendi dan tumit setelah bangun tidur pagi, kaku pada jari-jari tangan dan kaki, terjadi bengkak kemerahan di persendian klien yang menderita peningkatan asam urat. Peningkatan asam urat dipicu dengan tingginya konsumsi purin yang terkandung dalam beberapa makanan yang sering dikonsumsi masyarakat yaitu kacang-kacangan, jeroan, daging merah dan seafood.(Satriana, 2014). Prevalensi asam urat di dunia menurut World Health Organization (2018), mengalami kenaikan dengan jumlah 1370 orang (33,3 \%). Prevalensi asam urat juga meningkat pada kalangan orang dewasa di Inggris sebesar 3,2 \% dan Amerika Serikat sebesar 3,9. Di Korea prevalensi asam urat meningkat dari $3,49 \%$ per 1000 orang pada Tahun 2007 menjadi 7,58 \% per 1000 orang pada tahun 2015 (Kim, dkk, 2017). Hasil Riset Kesehatan Dasar (Riskesdas) tahun 2013, menyatakan bahwa prevalensi penyakit sendi di Indonesia berdasarkan diagnosis 
tenaga kesehatan (nakes) sebesar $11.9 \%$ dan di Provinsi Sulawesi Utara sebesar $10.3 \%$.

Berdasarkan survei epidemiologi yang bekerjasama dengan WHOCOPCORD di Bandungan Jawa Tengah, terhadap 4.683 sampel berusia antara 15 45 tahun, didapatkan kadar asam urat tinggi untuk laki-laki $24,3 \%$ dan untuk wanita $11,7 \%$, secara keseluruhan jumlah pravalensi adalah $17,6 \%$. Berdasarkan penyakit ini peningkatan kadar asam urat dalam darah pada laki-laki lebih tinggi dibandingkan dengan perempuan yang disebabkan akibat pengeluaran kadar purin pada perempuan yang dipengaruhi oleh siklus menstruasi yang tidak dialami oleh laki-laki. Asam urat tinggi juga sering dialami oleh wanita menopause oleh gangguan hormon (Dianati, 2015).

Penanganan yang dilakukan untuk mencegah terjadinya peningkatan kadar asam urat dalam darah, antara lain pengaturan diet, menghindari makanan tinggi purin, konsumsi vitamin dan mineral yang cukup, olahraga rutin, berhenti merokok, pengendalian stres dan dapat diberikan obat-obatan untuk terapi farmakologi. Pengobatan lain yang dapat digunakan untuk mengatasi peningkatan kadar asam urat yaitu dengan pengobatan herbal (Sari \& Syamsiyah, 2017).

Tanaman obat yang dapat digunakan untuk mengatasi asam urat antara lain seledri, sidaguri, kepel dan daun salam. Kandungan flavonoid, apigenin dan senyawa apiin dalam seledri yang bersifat deuretik dapat menambah jumlah air kencing sehingga purin dapat keluar melalui urin. Sidaguri berperan sebagai anti gout dengan mekanisme menghambat aktivitas enzim xanthine oksidase. Kemudian kandungan etanol dan heksan pada kepel berpotensi menurunkan kadar asam urat dalam darah setara obat Allopurinol. Sedangkan Dengan mengkonsumsi rebusan daun salam secara teratur dan sesuai dengan dosis yang dianjurkan yaitu $200 \mathrm{ml}$ di minum sekali dalam sehari dapat menurunkan kadar asam urat dalam darah (Ambarwati, 2017).

Berdasarkan Permenkes No.003/MenkesPer/I/2010 obat tradisional adalah bahan atau ramuan yang berupa bahan tumbuhan, bahan hewan, bahan mineral, sediaan sarian (galenik), atau campuran dari bahan tersebut yang secara turun temurun telah digunakan untuk pengobatan dan dapat diterapkan sesuai dengan norma yang berlaku di masyarakat.

Berdasarkan studi pendahuluan yang telah dilakukan peneliti didapatkan jumlah kunjungan penderita asam urat di Hatra R. bulan Juni - Agustus sebanyak 47 kunjungan. Data didapatkan dari data sekunder di Hatra R. pada tanggal 18 September 2019. Penyehat Tradisional (Hatra) R. Klaten Utara merupakan salah satu klinik pelayanan jamu jenis ramuan Indonesia yang beralamat di Gading Wetan, Belang Wetan RT 02 / RW 12, Klaten Utara, Klaten yang dibangun sejak tahun 2000. Pelayanan Jamu di Hatra R. sudah memiliki izin legalitas praktik berupa Surat Terdaftar Pengobat Tradisional (STPT). Klien yang datang di Hatra R. dengan asam urat diberikan terapi jamu berupa simplisia yang berisi kepel, sidaguri, meniran, temulawak dan kunyit dengan dosis pemakaian 3x sehari dengan cara direbus menggunakan air sebanyak 5 gelas hingga disisakan 3 gelas untuk diminum tiap pagi, siang dan malam 


\section{METODE PENELITIAN}

Sebuah studi kasus dengan seorang pasien wanita berusia 60 tahun dan memiliki kadar asam urat $9,6 \mathrm{mg} / \mathrm{dL}$. Penelitian dilakukan pada bulan Desember 2019 - Januari 2020. Klien di intervensi selama 4 minggu dengan metode pelayanan jamu.

\section{HASIL PENELITIAN}

Pengkajian dilaksanakan pada hari Senin, 16 Desember 2019 di Hatra R. Klaten Utara. Nama informan Ny. S dengan umur 60 tahun bertempat tinggal di Karangkulon RT 001/002, Bero, Trucuk, Klaten, beragama Islam mempunyai pekerjaan sebagai pedagang. Ny. S terakhir menimbang berat badan 65 $\mathrm{kg}$ dan tinggi badan $150 \mathrm{~cm}$ tidak mempunyai riwayat penyakit alergi. Klien mengatakan keluhan utama yang dirasakan yaitu pinggang hingga lutut bagian kanan sakit dan sulit untuk berjalan.

Riwayat penyakit yang diderita klien yaitu mengeluhkan pinggang hingga lutut kanan sakit dan sulit untuk berjalan, keluhan yang dirasakan sejak 2 tahun terakhir, serta klien merasakan jari-jari tangan dan kaki sangat kaku sehingga menganggu aktivitas sehari-hari dan klien mengatakan bahwa tidak mempunyai riwayat penyakit dahulu hanya saja ayahnya memiliki riwayat hipertensi. Klien pernah berobat ke puskesmas dengan mengkonsumsi obat allopurinol $100 \mathrm{mg}$, pieoxicam 10mg, dan asamfenamat 500mg dengan dosis $3 \times 1$ setelah makan.

Intervensi yang dilakukan pada klien yaitu melakukan observasi TTV yang didapatkan hasil TD : 158/83 mmHg, nadi : $76 \mathrm{x} / \mathrm{menit}$, pernafasan : 20 $\mathrm{x} / \mathrm{menit}$, suhu : $37^{\circ} \mathrm{C}$, dan $\mathrm{AU}: 9.6 \mathrm{mg} / \mathrm{dL}$.
Pemeriksaan fisik yang dilakukan secara head to toe dan didapatkan hasil rambut bersih dan tidak rontok, konjungtiva tidak anemis, telinga bersih tidak ada serumen, hidung bersih, lidah bersih, leher tidak ada benjolan atau pembesaran kelenjar tiroid. Dada (jantung dan paru-paru) bentuk normal, pergerakan normal tidak ada kelainan, suara normal. Abdomen, bentuk simetris, suara normal, pergerakan normal. Pinggang berbentuk normal tidak ada kelainan. Genetalia bentuk normal dan tidak ada kelainan.

Anus bentuk normal tidak ada kelainan. Ekstremitas atas terdapat gangguan dengan jari-jari tangan kaku dan sulit untuk ditekuk. Ekstremitas bawah terdapat gangguan nyeri pada pinggang hingga lutut bagian kanan dan sulit untuk berjalan. Mengkaji nyeri pada klien yaitu didapati hasil adanya nyeri tekan bagian sendi di kaki bagian kanan dengan skala nyeri 4, nyeri termasuk dalam kategori nyeri sedang. Kategori skala nyeri sedang yaitu skala 4-6. Memberikan racikan jamu untuk kadar asam urat dalam darah tinggi yang berupa Daun salam 20\%, Kumis kucing 10\%, Seledri 5\%, Bunga sidowayah $20 \%$, Sidaguri $15 \%$, Secang $10 \%$, Mahkota dewa 5\%, Cengkeh $5 \%$, Meniran 5\%, Temulawak 5\%. Jamu yang digunakan berupa ekstrak khusus untuk kadar asam urat dalam darah tinggi. Ekstrak tersebut berisi $250 \mathrm{ml}$ dalam satu botol.

Cara penggunaannya dengan minum 3 kali sehari 2 sendok makan setelah makan. Memberikan Konseling, Informasi dan Edukasi (KIE) yaitu mendiskusikan tanda dan penyebab asam urat, menganjurkan pola makan sehat dengan diet rendah purin, hindari makanan daging merah, jeroan, alkohol dan seafood, 
menganjurkan banyak minum air putih, menganjurkan pola hidup sehat dengan melakukan olahraga. Menganjurkan kontrol rutin ke griya sehat untuk mengetahui perkembangan penyakit. Evaluasi dilakukan di Hatra R. Klaten Utara dan rumah klien di Karangkulon RT 001/002, Bero, Trucuk, Klaten.

a. Evaluasi pertama pada tanggal 18 Desember 2019

(S) Subyektif : Klien mengatakan bahwa sudah ada perkembangan setelah minum jamu, nyeri yang dirasakan berkurang dan tidak terlalu sakit untuk berjalan.

(O) Obyektif : Hasil pemeriksaan tanda-tanda vital : TD 140/80mm/Hg, Nadi 80x/menit, suhu $37^{\circ} \mathrm{C}$, pernafasan $20 \mathrm{x} /$ menit, AU : $9.6 \mathrm{mg} / \mathrm{dL}$. Raut wajah klien tampak tidak menahan rasa sakit.

(A) Analisa : Tujuan tercapai sebagian, klien mengatakan bahwa pinggang hingga lutut yang terasa nyeri sudah mulai berkurang.

(P) Perencanaan: pemberian jamu dilanjutkan, lebih sering memantau perkembangan klien, memantau pola makan, anjuran dan larangan yang diberikan.

b. Evaluasi kedua pada tanggal 21 Desember 2019

(S) Subyektif : Klien mengatakan bahwa sudah ada perkembangan lebih baik setelah minum jamu, nyeri yang dirasakan berkurang, tidak terlalu sakit saat berjalan dan jari-jari tangan serta kaki mulai lemas.

(O) Obyektif : Hasil pemeriksaan tanda -tanda vital : TD $137 / 78 \mathrm{~mm} / \mathrm{Hg}$, Nadi $80 \mathrm{x} / \mathrm{menit}$, suhu $37^{\circ} \mathrm{C}$, pernafasan $20 \mathrm{x} /$ menit, $\mathrm{AU}: 7.1$ $\mathrm{mg} / \mathrm{dL}$. Klien terlihat tidak menahan nyeri, klien terlihat lebih tegak dalam berjalan, bengkak pada lutut klien berkurang

(A) Analisa : Tujuan tercapai sebagian, klien mengatakan bahwa nyeri yang dirasakan berkurang dan jarijari tangan serta kaki mulai lemas.

(P) Perencanaan : pemberian jamu dilanjutkan, lebih sering memantau perkembangan klien, memantau pola makan, anjuran dan larangan yang diberikan.

c. Evaluasi ketiga pada tanggal 24 Desember 2019

(S) Subyektif : Klien mengatakan bahwa sudah ada perkembangan yang jauh lebih baik setelah minum jamu, nyeri yang dirasakan berkurang, jalan mulai normal dan jari-jari tangan serta kaki tidak kaku.

(O) Obyektif : Hasil pemeriksaan tanda -tanda vital : TD $130 / 75 \mathrm{~mm} / \mathrm{Hg}$, Nadi $78 \mathrm{x} /$ menit, suhu $36^{\circ} \mathrm{C}$, pernafasan $20 \mathrm{x} /$ menit, AU : 6.5 mg/dL. Klien tampak lebih bahagia, bengkak dan kemerahan pada lutut kanan klien kembali normal, dan jari-jari tangan serta kaki klien tidak kaku.

(A) Analisa : Tujuan tercapai sebagian, klien mengatakan bahwa nyeri yang dirasakan berkurang, jalan mulai normal dan jari-jari tangan serta kaki tidak kaku.

(P) Perencanaan: pemberian jamu dilanjutkan, lebih sering memantau perkembangan klien, memantau pola makan, anjuran dan larangan yang diberikan.

d. Evaluasi keempat pada tanggal 27 Desember 2019

(S) Subyektif : Klien mengatakan bahwa sudah sangat membaik 
setelah minum jamu, nyeri yang dirasakan sudah hilang, tidak sakit untuk berjalan dan jari-jari tangan serta kaki sudah normal.

(O) Obyektif : Hasil pemeriksaan tanda -tanda vital : TD $130 / 75 \mathrm{~mm} / \mathrm{Hg}$, Nadi $76 x /$ menit, suhu $36.5^{\circ} \mathrm{C}$, pernafasan 20x/ menit, AU : 6.1 $\mathrm{mg} / \mathrm{dL}$. Klien tampak bahagia, bengkak dan warna kemerahan pada lutut kanan klien hilang, klien tampak berjalan normal, serta jarijari tangan dan kaki klien tidak kaku.

(A) Analisa : Tujuan tercapai sebagian dimana mendekati kadar asam urat normal

(P) Perencanaan : pemberian jamu dihentikan, lanjutkan intervensi dan konseling.

e. Evaluasi ke lima pada tanggal 4 Januari 2020

(S) Subyektif : Klien mengatakan bahwa sudah sembuh setelah minum jamu, nyeri yang dirasakan sudah hilang, tidak sakit untuk berjalan dan jari-jari tangan serta kaki sudah normal.

(O) Obyektif : Hasil pemeriksaan tanda-tanda vital : TD $125 / 75 \mathrm{~mm} / \mathrm{Hg}$, Nadi 76x/menit, suhu $36.5^{\circ} \mathrm{C}$, pernafasan $20 \mathrm{x} /$ menit, AU : $6.0 \mathrm{mg} / \mathrm{dL}$. Klien tampak bahagia, bengkak dan warna kemerahan pada lutut kanan klien hilang, klien tampak berjalan normal, serta jari-jari tangan dan kaki klien tidak kaku.

(A) Analisa : Tujuan tercapai dimana masalah teratasi

(P) Perencanaan: pemberian jamu dihentikan, lanjutkan intervensi dan konseling

\section{PEMBAHASAN}

Hasil pengkajian yang dilakukan pada Ny. S mengatakan pinggang hingga lutut sebelah kanan nyeri dan bengkak di lutut, untuk berjalan sakit dan sudah dirasakan sejak 2 tahun terakhir. Berdasarkan tanda dan gejala pada Ny. S yaitu nyeri pada kaki saat melakukan gerakan ringan seperti berjalan, bengkak, kaku pada jari-jari tangan dan kaki. hal ini sesuai dengan teori Junaidi (2009) bahwa gejala utama pada asam urat yaitu bengkak pada sendi, berwarna kemerahan, nyeri saat digerakkan.

Penentuan skala nyeri pada klien berdasarkan cara pengukuran intensitas nyeri menurut Wong-Bakers nyeri yang dialami klien yaitu skala 4 (kategori sedang) dimana hasil tersebut sesuai dengan penelitian Aisyah (2017) nyeri sedang yaitu skala 4-6 dan secara obyektif klien tampak menahan rasa sakit dan sulit untuk berjalan. Pemeriksaan TTV didapatkan hasil TD : 152/83 mm/Hg, Nadi : 76x/menit, Pernafasan : 20x/menit, Suhu : $37^{\circ} \mathrm{C}$. Data penunjang pemeriksaan asam urat klien sebesar 9,6 ml/dL hal ini sesuai dengan penelitian Sholihah (2014) bahwa asam urat tinggi didefinisikan sebagai peninggkatan kadar asam urat, normal asam urat (wanita $>6.0 \mathrm{ml} / \mathrm{dL}$ ).

Ny.S memiliki keluhan utama yaitu nyeri pada pinggang hingga lutut bagian kanan serta kaku pada jari-jari tangan dan kaki, berdasarkan pemeriksaan penunjang diperoleh hasil asam urat : 9,6 mg/dl, sehingga Ny. S diagnosa dokter mengalami Hiperuresemia. Diagnosa emik atau berdasarkan Hatra R. yaitu kadar asam urat dalam darah tinggi.

Perencanaan yang dilakukan oleh peneliti yaitu, mengkaji karakteristik nyeri dengan menggunakan metode (PQRST) yaitu Provoking pada Ny. S, klien 
mengatakan bahwa nyeri timbul apabila digunakan untuk berjalan. Quality : nyeri seperti tertusuk jarum, Region : lokasi nyeri di sendi kaki kanan dan pinggang, Severity : skala nyeri 4 . Tanda-tanda vital klien mulai dari tekanan darah yaitu $152 / 83 \mathrm{~mm} / \mathrm{Hg}$, denyut nadi $76 \mathrm{x} / \mathrm{menit}$, pernafasan $20 \mathrm{x} /$ menit, dan suhu $37^{\circ} \mathrm{C}$ yang sudah sesuai dengan teori Mubarak (2008) dalam Wahyuningtyas (2013) menggunakan pengkajian nyeri dengan metode (PQRST).

Memberikan konseling, informasi dan edukasi (KIE) kepada klien. Keluhan yang dialami Ny. S disebabkan oleh konsumsi kacang-kacangan, jeroan, telur, ikan dan jamur.. Hal ini sesuai dengan penelitian Dianti (2015) bahwa purin hewani lebih berpengaruh terhadap kenaikan asam urat dibandingkan dengan purin nabati. Makanan dan minuman pemicu asam urat tinggi antara lain jeroan, daging sapi, daging babi, daging kambing atau makanan dari hasil laut, kacangkacangan, bayam, jamur, kembang kol, sarden, kerang, minuman beralkohol.

Pada tahap pengambilan tindakan digunakan serangkaian kegiatan yang dilakukan untuk membantu klien dari masalah kesehatan yang dihadapi kestatus kesehatan yang baik sesuai dengan yang diharapkan. Pemberian racikan jamu asam urat tinggi pada klien diberikan berupa ekstrak cair untuk asa urat yang isinya terdiri dari daun salam $20 \%$, bunga sidowayah $20 \%$, sidaguri $15 \%$, kumis kucing $10 \%$, secang $10 \%$, mahkota dewa $5 \%$, cengkeh $5 \%$, seledri $5 \%$, meniran $5 \%$, temulawak $5 \%$.

Analisis ramuan jamu untuk menurunkan asam urat tinggi, daun salam berdasarkan hasil penelitian Tari et al (2018) Penurunan kadar asam urat sesudah pemberian air rebusan daun salam dipengaruhi oleh kandungan flavonoid yang bersifat antioksidan yang dapat menghambat enzim xanthine oxidase sehingga pembentukan asam urat dalam tubuh terhambat serta dipengaruhi juga oleh kandungan tritepen, polyphenol, dan alkaloid yang bersifat diuretik yang memproduksi urin lebih banyak sehingga asam urat keluar melalui urin.

Cengkeh digunakan sebagai analgetik dan antiinflamasi karena kandungan minyak atsirinya (Kemenkes, 2011) sedangkan menuurut penelitian Setiani dan Wiwi (2010) bahwa pemberian air rebusan cengkeh efektif terhadap penurunan asam urat pada usia lanjut.

Analisis ramuan jamu penurun tekanan darah, seledri yang berfungsi untuk menurunkan tekanan darah karena mengandung apigenin (Kemenkes, 2017) hal ini sesuai dengan penelitian Saputra dan Triola (2016) bahwa kandungan apigenin pada seledri bersifat vasorelaksator dengan mekanisme penghambatan kontraksi yang disebabkan oleh pelepasan kalsium yang bekerja dengan menurunkan tekanan darah.

Secang digunakan sebagai anti analgesik dan penghambatan aktivitas enzim xantin oksidase karena aktifitas senyawa fenol (Kemenkes, 2017). Hasil penelitian yang telah dilakukan oleh Permatawati dan Mutia (2015) memperlihatkan bahwa ekstrak kulit kayu secang mampu menghambat aktivitas enzim xantin oksidase sampai $56,47 \%$.

Sidaguri memiliki sifat khas manis dan mendinginkan. Kandungan utama tanaman adalah flavonoid, saponin, alkaloid dan glikoksida yang dapat digunakan sebagai antigout dengan mekanisme menghambat aktivitas enzim xanthine oksidase (Kemenkes RI, 2016). 
Kumis kucing memiliki efek sebagai diuretik karena mengandung senyawa inositol dan flavonoid sinensetin (Kemenkes, 2017) hal ini dibuktikan oleh penelitian Supari (2002) bahwa kumis kucing memiliki efek diuretik dominan untuk menurunkan tekanan darah tinggi.

Temulawak mengandung senyawa kurkumin yang bermanfaat sebagai antihepatotoksik (BPOM RI, 2006) hal ini dibuktikan dengan penelitian Candra (2013) Kurkumin pada temulawak mempunyai efek anti peradangan, antioksidan, antibakteri, imunostimulan, kolagogum, hipolipidemik, hepatoprotektor, dan tonikum.

Upaya pencegahan untuk Ny.S meliputi memperbanyak konsumsi air putih minimal $2 \mathrm{~L}$ perhari, memperbanyak konsumsi sayur dan buah yang berserat, rendah gula, rendah lemak, mengurangi konsumsi garam, mengurangi makanan yang manis-manis, menghindari makanan dengan kandungan purin tinggi (kedelai, bayam, jeroan, kacang-kacangan, daging kambing) hal ini sesuai menurut Kenemkes (2013) bahwa upaya pencegahan klien dengan asam urat tinggi antara lain dengan mengatur pola makan (kurangi makanan yang mengandung purin tinggi seperti, hati, ginjal, otak, jeroan, udang, kerang, sardine, daging sapi, daging kambing, ragi (tape), kacangkacangan, kembang kol, bayam, jamur, daun singkong, daun papaya, kangkung), menghindari alkohol, banyak minum air putih, menurunkan berat badan dengan olahraga, menggunakan air hangat untuk mandi karena air hangat dapat memperlancar pergerakan sendi, istirahat yang cukup di malam hari 8 hingga 9 jam per hari.

\section{KESIMPULAN DAN SARAN}

Kesimpulan penelitian yaitu pengkajian pada Ny. S dengan kadar asam urat dalam darah tinggi dengan keluhan utama nyeri pada pinggang hingga lutut bagian kanan. Klien mengatakan lutut sebelah kanan bengkak dan memar, kaki sulit untuk berjalan dan sudah berlangsung selama kurang lebih 2 tahun. Perumusan masalah yang dapat dibuat pada Ny. S adalah diagnosis dari dokter (etik) yaitu hiperuresemia dan diagosa dari tenaga kesehatan tradisional yaitu kadar asam urat dalam darah tinggi dengan nyeri pada pinggang hingga lutut bagian kanan nyeri dan sudah berlangsung selama 2 tahun. Perencanaan yang diberikan pada Ny. S yaitu kaji karakteristik nyeri dan tanda-tanda vital, lakukan pemeriksaan fisik ekstremitas bawah (kaki), berikan ramuan jamu untuk kadar asam urat tinggi, berikan KIE pada klien.

Pelayanan jamu yang diberikan pada klien yaitu mengkaji karakteristik nyeri dan tanda-tanda vital, melakukan pemeriksaan fisik ekstremitas bawah (kaki), memberikan ramuan jamu untuk klien dengan asam urat tinggi, memberikan KIE pada klien Evaluasi yang didapati pada $\mathrm{Ny}$. S dengan kadar asam urat tinggi yaitu masalah teratasi dimana nyeri pada pinggang hingga lutut bagian kanan hilang, bengkak dan memar pada lutut kembali normal dan klien dapat berjalan dengan normal. Perencanaan pada Ny. S untuk menghentikan konsumsi ramuan sediaan jamu, menjaga pola makan dengan menerapkan anjuran dan larangan pada saat konseling dengan tenaga kesehatan tradisional, melakukan latihan fisik ringan seperti jalan santai. 
Pelayan jamu diharapkan memberikan konseling lebih tentang pendidikan kesehatan tentang asam urat tinggi seperti memberi leflet kepada klien tentang asam urat yang melitputi pengertian, tanda dan gejala, faktor penyebab, faktor resiko, klasifikasi, penatalaksanaan secara non farmakologi.

\section{DAFTAR RUJUKAN}

Martha, E., \& Kresno, S. (2016). Metodologi Penelitian Kualitatif. Jakarta : Rajawali Press.

Satori \& Komariah. (2017). Metodologi Penelitian Kualitatif. Bandung: Alfabeta.

Setiadi. (2012). Konsep dan Penulisan Dokumentasi Asuhan Keperawatan Teori dan Praktik. Yogyakarta : Graha Ilmu.

Sugiyono. (2018). Metode Penelitian Kuantitatif,Kualitatif,dan $\quad R \& D$. Bandung: Alfabeta.

Thayibah, R, dkk. (2018). Hiperurisemia Pada Remaja di Wilayah Kerja Puskesmas Arjasa Kabupaten Situbondo. Jurnal Pustaka Kesehatan. Vol 6 (1) : 38-45.

Naid, T., Ayuningsih, Mas'ud., \& Haryono Kus. (2014). Korelasi Kadar Asam Urat Dalam Darah Dan Kristal Asam Urat Dalam Urine. Jurnal AsSyifaa Vol 06 (01) : 56-60.

Ndede, Vechya Z.L.P., dkk. (2019). Pengaruh Pemberian Rebusan Daun Salam Terhadap Penurunan Kadar Asam Urat Pada Penderita Gout Arhtritis Di Wilayah Kerja
Puskesmas Ranotana Weru. E-journal Keperawatan (e-Kp) Vol.7 (1):1-6

Untari I., Sarifah S., \& Sulastri. (2017). Hubungan Antara Penyakit Gout Dengan Jenis Kelamin Dan Umur Pada Lansia. Jurnal The 6 University Research Collaquium UMY Magelang ISSN 2407-9189.

Kemenkes RI. (2010). Permenkes RI No. O03/MENKES/PER/I 2010. Jakarta: Menteri Kesehatan RI.

Kemenkes RI. (2014). Peraturan Pemerintah Republik Indonesia Nomor 103 Tahun 2014 Tentang Pelayanan Kesehatan Tradisional.

Depkes RI. (2016). Farmakope Herbal Indonesia. Jakarta: Departemen Kesehatan Republik Indonesia.

Ambarwati Siti. (2012). Pengaruh Pemberian Air Rebusan Seledri Terhadap Kadar Asam Urat Pada Penderita Arhtitis Gout Di Kelurahan Prawirodirjan Yogyakarta.

Boleu I. Fiktor, dkk. (2018). Pengaruh Dan Hubungan Antara Asam Urat Darah Dengan Gula Darah Sewaktu Dan IMT Pada Komunitas Etnik Asli Di Halamahera Utara. Jurnal Ilmu Kesehatan Masyarakat 9(2):96-106

Nasrul E. \& Sofitri. (2012). Hiperuresemia Pada Pra Diabet Jurnal. Kesehatan Andalas: 1(2)

Linarwati Mega. (2016). Studi Deskriptif Pelatihan Dan Pengembangan Sumber Daya Manusia Serta Penggunaan Metode Behavioral Even 
Interview Dalam Merekrut Karyawan. Ningtiyas F. (2016). Efektivitas Ekstrak Jurnal of Management, Vol.2 No.2. Daun Salam Untung Menurunkan Kadar Asam Urat Pada Penderita

Dianati. (2015). Gout dan Hiperurisemia. Jurnal Majority 4 (3) : 82-89. Artritis Gout. Jurnal Majority; 5(3): $1-6$

Fauzan, A. (2016). Hubungan Indeks Massa Tubuh (IMT), Asupan Purin dan Olahraga dengan Kejadian Gout Arthritis pada Lansia di Wilayah Kerja Puskesmas Tanjungsari Pacitan. [Skripsi]. Fakultas Ilmu Kesehatan Universitas Muhammadiyah Surakarta.

Lina, N dan Setiyono, A. (2014). Analisis Kebiasaan Makan yang Menyebabkan Peningkatan Kadar Asam Urat. Jurnal kesehatan komunitas Indonesia; 10(2): 10441015.

Aldi et al. (2014). Aktivitas Imunomodulator dari Ekstrak Etanol Meniran (Phyllanthus niruri Linn.) terhadap Ayam Broiler. Jurnal Sains Farmasi dan Klinis; 1(1)

Ariani, D.R. (2014). Hubungan Tingkat Pengetahuan Penderita Asam Urat dengan Kepatuhan Diet Rendah Purin di Gawanan Timur Colomadu Karanganyar. Program Studi Keperawatan Stikes Kusuma Husada. Surakarta.

Ayurini, B.D. (2010). Pengaruh Ekstrak Etanol Rimpang Kunyit terhadap Jumlah Geliatan Mencit yang Diinjeksi Asam Asetat 0,1\% [Artikel Ilmiah]. Program Pendidikan Sarjana Kedokteran Universitas Diponegoro. Semarang. 